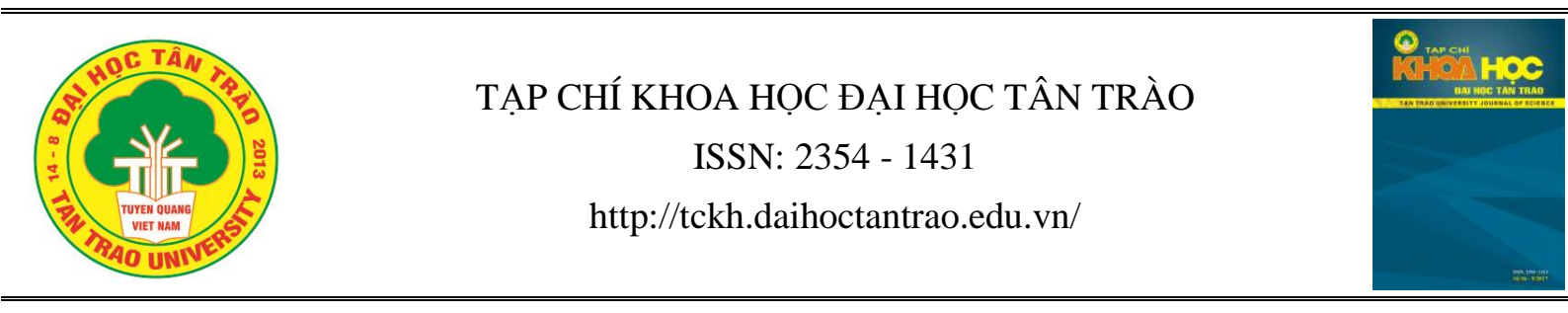

\title{
OVERVIEW OF RESEARCHES ON ENGLISH TEACHING AND LEARNING: ENGLISH FOR SPECIFIC PURPOSES
}

\author{
Nguyen Thi Huong Lan ${ }^{1, *}$ \\ ${ }^{1}$ Hanoi Law University, Vietnam \\ *Email address: bihuonglan@gmail.com \\ https://doi.org/10.51453/2354-1431/2021/601
}

\section{Article info}

Recieved: $23 / 7 / 2021$

Accepted: 05/9/2021

\section{Keywords:}

Researches ESP, teaching and learning ESP, lingua franca scholars

\begin{abstract}
The increasing demand of English for Specific Purposes (ESP) has resulted in the need for a lingua franca of science, technology, education, and business. The field of ESP has promptly flourished recently to play an important part in English language teaching and research. Accordingly, the desires to master technical terms to meet job requirements force people to know ESP rather than basic English for daily communication. Researches on teaching and learning ESP have been conducted widely not only in Vietnam but other countries by high prestigious scholars and knowledgeable researchers with the main purpose to figure out the most effective approaches, which enables educators, teachers and learners as well to adapt the best teaching methods to accomplish their wishes. Based on material research methodology, an overview of studies on teaching and learning ESP both inside and outside Vietnam, as well as background knowledge on ESP teaching and learning, the researcher indicates the challenges, opportunities and benefits brought to teachers and learners in ESP training.
\end{abstract}


TẠP CHÍ KHOA HỌC ĐẠI HỌC TÂN TRÀO

ISSN: $2354-1431$

http://tckh.daihoctantrao.edu.vn/

\title{
TỔNG QUAN NGHIÊN CÚU VỂ DẠY VÀ HỌC TIẾNG ANH CHUYÊN NGÀNH
}

\author{
Nguyễn Thị Hương Lan ${ }^{l, *}$ \\ ${ }^{1}$ Truờng Đại học Luật Hà Nội, Việt Nam \\ *Địa chỉ email: bihuonglan@gmail.com \\ https://doi.org/10.51453/2354-1431/2021/601
}

\section{Thông tin bài viết}

Ngày nhận bài:23/7/2021

Ngày duyệt đăng:05/9/2021

\section{Tù khoá:}

Nghiên cưu Tiếng Anh chuyên ngành, Giảng dạy tiếng Anh chuyên ngành, Ngôn ngũ chung, Học giả

\begin{abstract}
Tóm tắt
Nhu cầu ngày càng cao về tiếng Anh chuyên ngành đòi hỏi phải có một ngôn ngữ chung cho các ngành khoa học, công nghệ, giáo dục và kinh doanh. Lĩnh vực tiếng Anh chuyên ngành phát triển gần đây đóng vai trò quan trọng trong việc giảng dạy và nghiên cứu tiếng Anh. Do vậy, nhu cầu thành thạo thuật ngữ tiếng Anh đáp ứng công việc buộc họ phải biết tiếng Anh chuyên ngành thay vì tiếng Anh cơ bản cho mục đích giao tiếp thông thường. Nghiên cứu được thực hiện bởi các học giả và các nhà nghiên cứu uy tín về giảng dạy tiếng Anh chuyên ngành trong cũng như ngoài nước với mục đích đề xuất những phương pháp giảng dạy hiệu quả nhất giúp cho các nhà giáo dục, giáo viên và người học thích nghi được những phương pháp giảng dạy hữu hiệu nhằm đạt được kỳ vọng của họ. Dựa trên những phương pháp nghiên cứu tài liệu, những khảo cứu về kiến thức tiếng Anh giảng dạy tiếng Anh chuyên ngành trong và ngoài nước cũng như sự hiểu biết về tiếng Anh chuyên ngành, tác giả đã nêu ra những thách thức, cơ hội và lợi ích mang lại cho người dạy và người học khi học tiếng Anh chuyên ngành.
\end{abstract}

\section{Introduction}

In 1960s, the emergence of the term "ESP" enabled people to raise awareness that general English courses frequently did not meet learners' or employers' needs [1]. As English is regarded as a lingua franca in business, media, technology, medicine, education, and research, the demand for ESP is growing rapidly. In EFL countries like Vietnam, people learn English to fulfill the school curriculum requirements, to pass standardized English proficiency tests, or to obtain promotion or professional development at work. Instead of learning ESP, it seems better to learn English relating to their professional fields so that they can easily find a future job or get promoted at work.
More and more universities are currently offering ESP courses to meet the demand of workability and to satisfy students' future career expectations. In Vietnam, ESP courses are not applied fully, but it would be better if they are. Through many different companies' interviews, employers are claiming that they are searching specialized people to work for them, but they have difficulty in finding those persons. Therefore, English for general purposes (EGP) should be the basic language learning to be studied before ESP courses. Thus, ESP must be adjusted to match students' study major. One more reason is that at tertiary level, students are trained to perform on- 
the-job. So, compared with EGP, ESP is more effective in enhancing students' learning motivation with regard to their fields of study and meeting their needs. Needless to say, teaching and learning English, especially ESP becomes more practical and effective thanks to educational researchers' tasks. Particularly, what have they done? Which problems have they named? And how have they done to resolve them? To highlight the things that have been figured out by researchers, we need to learn about some background of ESP in language teaching and learning.

\section{English for Specific/Academic Purposes (ESP)}

\subsection{Definition of ESP}

Many ESP definitions have been coined until now. Strevens [2] defines it as absolute and variable characteristics. The absolute characteristics entail: designed to meet certain learners' needs; related to contents to particular specializations, occupations, or activities; focused on language suitable for those activities in syntax, discourse, semantics, and analysis of the discourse; not like 'general English'. Besides, the variable characteristics include: ESP may be limited to learning certain skills; it may not be taught based on any pre-planned methodology. Robinson's definition [3] is based on two important criteria and two characteristics. The two standards are that ESP is 'normally goal - oriented' and that ESP courses rely on needs analysis determining what students learn. Robinson shares the same opinion with Hutchinson and Waters [4] on the importance of need analysis. ESP courses are taught in a limited period and are made up of groups of adult learners who have the same job and area of specialization [3]. In their definition of ESP, Dudley-Evans and St John [5] also employ absolute and variable characteristics. The absolute characteristics encompass: ESP is developed to cater certain learners' needs; it uses the methodology and the tasks of the field it serves, and it focuses on the language (grammar, lexis, and registers), skills, discourse, and genres suitable for these tasks. The variable characteristics contain: ESP may be planned for a specific specialization; it may apply a varied methodology from that of general English; it is probably designed for adult learners, yet it could be taught to secondary school level students; and it is designed for students with higher language level because it anticipates basic knowledge of the language. However, it can be taught to beginners [5].

\subsection{Types of ESP}

ESP is generally divided into two main classes: English for academic purposes (EAP) and English for occupational purpose (EOP). In which EAP is further subdivided into four branches: English for science and technology (EST) has been the main branch; however, English for medical purposes (EMP) and English for legal purposes (ELP) have always had their place. English for management, finance, and economics (EMFE) is a recent branch, which has increasingly become important for Master of Business Administration Courses, but no specific acronym has been established for it [5]. Hyland [1] propounds that EAP has become popular due to the large numbers of international learners studying in British and American universities. Therefore, these universities provide EAP courses to better learners' academic communication skills in English to match the standards required for university entry where English is the medium of instruction. EAP caters to communication skills in the English language demanded in academic situations in official education systems for study reasons [6]. He also distinguishes between two types of EAP. Those courses aimed at general academic purposes are called English for general academic purposes (EGAP), in which content of interest for a variety of academic fields is taught. The other type is English for specific academic purposes (ESAP) which is oriented to learners from a particular academic field. Most ESP work can be done by EAP which is considered a branch of the former. It is teaching the language for specific purposes to those interested in joining academic studies. According to Robinson [3], materials in EAP courses may be aimed at students from a wide variety of academic disciplines. Within such general courses, we might find components intended to students from specific disciplines'. EAP, according to Hyland [1], is teaching English language for certain fields based on the social, intellectual, and linguistic requirements of the academic target situation. The teaching is oriented 
by a comprehension of texts and the restrictions in the situation.

\subsection{Characteristic feature of ESP course}

Another unforgotten thing is the organization of course which should be a different curriculum with different types of exercises and materials. Actually, organizing an ESP course requires a decisive step to achieve learning outcome. There are many existing factors playing a crucial role in constructing ESP course. The term 'specific' in ESP refers to a specific purpose for which English is learned and teachers should be familiar with. They should be able to find an answer to what Hutchinson and Waters [4] describe as 'language description'. The 'language description' involves questions, e.g. What topic areas will need to be covered? What does the learner need to learn? What aspects of language will be needed and how will they be described? They give out 'learning theory' which provides the theoretical basis for the methodology. Naturally, learning strategies vary and correspond with learners' groups, their ages, levels or reasons they study. The way adults acquire a language not the same as children, the group of advanced expects different attitude from beginners, so teachers determine which aspects of ESP learning should be focused on to meet learns' needs and expectations successfully. Hutchinson and Waters [4] point out another aspect affecting the ESP course. It relates to learner's surrounding and discusses the question of 'who', 'why', 'where', and 'when' connected with the nature of particular target and learning situation. They describe them as 'needs analysis'. To organize the ESP course effectively, having respect for all three factors is demanding as follows:

Selecting material: Choosing ESP materials determines the running of the course and underlines content of the lesson. Good materials help teachers organize the course as an introduction into the new learning techniques, and support teachers and learners in the process of learning. Materials are also a kind of teacher reflection, 'they should truly reflect what you think and feel about the learning process' [4]. Good materials should be based on various interesting texts and activities providing a wide range of skills. Teachers determine which aspects of ESP learning are focused on but one piece of material can serve for developing more than one skill, e.g. reading, listening, vocabulary, etc. Materials should act as a link between existing knowledge and new information.

Types of activities with text: Text as a learning material can be used for learning and practicing wide range of skills. In ESP course, it can be a source for new vocabulary, communicative or reading skills. To make working with a text as much effective as possible, it is necessary to involve all students' skills. It is preferred to combine working with printed text with listening to audio-cassette or video - cassette which means receptive with productive activities. Concerning the ESP activities, the context should be consistent with studying subject matter.

Creating a learning environment - motivation: The last criterion is very important should be applied during such courses. Creating a positive learning atmosphere in the classroom is a primary step for achieving setting objectives and goals. It makes teaching and learning more pleasant for both sides of the process, for a teacher and a learner, and it supports learners in their work. Creating a positive learning atmosphere is closely linked with motivation. Motivation is also an influent and necessary part of students' work affecting their future success or failure. It is a kind of inner motor promoting us to do our best to achieve a satisfactory goal in our activities. Harmer [7] describes motivation as 'some kind of internal drive that encourages somebody to pursue a course of action' The role of motivation during each activity is inevitable. Learners should be motivated as much as possible to enjoy the activity and achieve its real aim.

\section{Theories on Teaching and Learning ESP}

The fact that 'learners know specifically why they are learning a language' [4] is a great advantage on both sides of the process. Learners' motivation, in a form of the same aim, enables teachers to meet learners' needs and expectations easier. Learners and their acquiring language are considered the main factors in the whole process. Hutchinson and Waters [4] emphasize ESP to be an approach, not product that means language learning, not language use is highlighted. They focus on 'learning - centered approach' "in which 
all decisions as to content and method are based on the students' reason for learning".

\subsection{The roles of teacher in English for Specific Purposes (ESP)}

Widdowson [8] argues that the term 'role' is used in various ways, but generally, a 'role' is defined as a part of the performance in a certain social action. In language teaching, a role determines the status of both teachers and learners, and it is subject to change, depending on the kind of activities happening in the classroom. DudleyEvans and St John [5] proposed five roles for the teacher, such as a course designer and material provider, researcher, collaborator, and evaluator.

As a 'teacher': It is obvious that the ESP teacher teaches the English language. However, the difference lies in the objective behind teaching [7]. In ESP course, a teacher does not mean only being a language provider, but also as a needs analyst. Since the teacher is not the primary knower of the career content of the discipline, he/she has to understand his/her learners' wants to understand their knowledge of the content. Therefore, it can bring the relevant materials required by the group of learners in class.

As a course designer and materials provider: ESP course is to motivate the learners to use English both in an academic and professional setting. Therefore, both ESP courses and materials are based on analyzing learners' needs [9]. Course makers should realize some basic questions before designing any courses. The teachers can modify the activities to suit the learners' wishes, and in case both possibilities are not in hand, the ESP teachers can generate their own [5]. Hutchinson and Waters [4] suggest some tips related to 'materials providing'. It is not always right that materials and courses are formed according to the learners' needs. However, teachers and sponsors' needs are taken into account because if the teacher is not satisfied with the material, the thing he/she will provide would affect the learners by losing and decreasing their motivation.

As collaborator: The activities such as coordinating with colleagues are considered to be an essential step in any educational task. An ESP teacher does not have an exception since one of his/her roles is to cooperate with the subject skills, tasks, and syllabus, also discover how the subject integrates with the language to bring the suitable material and courses for the learners [5].

As a researcher: ESP plays a far-reaching position in English language teaching (ELT) all over the world. It shows its way from language theories and research [1]. Hence, the process of teaching ESP is restricted or limited to the findings in linguistic research in the target subject-specialty [9]. This means the ESP teachers have to research their own goal 'in what they want to achieve. Then, before designing course or providing materials, the teachers need to do the researches in investigating the genres of texts, language, and skills required by the specific field of study [5].

As an 'evaluator': Evaluation is no exception to being an unconscious activity in our daily life. In language teaching, evaluation plays a role as feedback for learners and the course achievement [5]. Evaluation should be carried out by the teachers because the teachers knows the learners' strengths and weaknesses. Furthermore, they are expected to understand the classroom problems and determine the kind of evaluation which is relevant to their learners.

Teachers are involved in different types of evaluation. Dudley-Evans \& St John [5] state that in the context of ESP, there are two types of evaluation. First, the learners' evaluation in which the teacher assesses whether students have the necessary language and skills to survive in the academic course or career, and in which they assess the level of their achievement. Second, evaluation of the course and the teaching materials to measure the extent to which suit the learners' needs.

3.2. The role of Students/ learners in English for Specific Purposes (ESP)

As a beneficiary/a client: Deeply, learners in an ESP class require a certain English that meets their specific requirements. ESP refers to the teaching and learning of English as a second or foreign language where learners' purpose is to use English in a specific domain. The learners are in ESP class with a specific interest in learning, subject matter knowledge, and well-built adult learning strategies. Learners are in charge of developing English 
language skills to reflect their native-language knowledge and skills. They also have opportunities to understand with a language in a context that they comprehend and know.

As an acquirer: In this context, ESP brings students a powerful means for such opportunities. The learners will acquire English as they work with materials which they find interesting and relevant to their professional work or even further studies. Learners in the ESP classes are generally aware of the purposes they will need to use English. Knowledge of the subject area enables the learners to identify a real context for the vocabulary and structures of the ESP classroom. They are constantly expanding vocabularies, becoming more fluent in their fields, and adjusting their linguistic behavior to new situations or new roles. ESP students can exploit those innate competencies in learning English.

4. Overview of Researches on Teaching and Learning English for Specific Purpose (ESP)

\subsection{Research situation on ESP teaching and learning in Vietnam}

Up to now, the number of published researches conducted on teaching and learning ESP in Vietnam is limited. However, their topics overviewed mainly focus on following issues:

* Theories and methodologies of ESP teaching and learning.

Theoretical background is a firm framework to structure a scientific and practical syllabus. Forming an ESP syllabus is not an exception, which requires fully theoretical principles. The most outstanding research is Dong [10], in which he ensures that planning a sufficient policy on ESP teaching and learning, building an ESP teaching syllabus, and choosing an ESP textbook cannot be done without investigating and analyzing needs of learners, education managers, employers and others concerned. This guarantees that a formed ESP syllabus does meet both their demands and aims, and it also makes sense of the name 'ESP' itself. In another research, $\mathrm{Ha}$ [11] states that to develop a syllabus for ESP, it is unavoidable to approach results - final products of studying and learners' competence, shape principles and fundaments of syllabus formation. Phuong [12] points out strong and weak points of 3 theoretical frameworks in assessing ESP syllabus, namely course assessing framework [4], assessing syllabus framework [8], and updated framework of assessing ESP syllabus [13].

* Problems of teaching ESP and solution to enhance ESP teaching quality

Clearly, looking for synchronized and practical solutions is a highly concerned issue of school administrators. To do this effectively, problems must be specified. Dung and Anh [14] mention some opportunities and challenges, as well as teaching and learning ESP situations at some keypoint educational premises across the country; policies on curriculum and textbook, ESP teachers and teaching methodologies, learners' attitude and competency, assessment principles. They also propose some solutions to these problems such as; analyzing society needs, building a general route on curriculum, length of course, textbooks; setting a placement test to classify learners' level in order to enhance their knowledge acquisition ability, creating intensive training courses for teachers, developing teaching materials, forming a set of questions for exams on national standard or international standard. In Binh's study [15], he proposes to improve educational quality in globalization and rank up the importance of teaching and learning ESP, teaching and learning ESP must be taken in charge by teachers of English. Besides, it is essential for learners of ESP need to meet prerequisites at starting point with at least B1 (pre-intermediate) or B2 (intermediate). Specially, ESP curriculum designation needs carrying out on general principles, reasonable time lines, and basing on analysis the needs of society, learners, curriculum designers, teaching methodologies and assessing methodologies. Furthermore, it is vital to distinguish ESP teaching from teaching major in English scientifically. Because approaching purposes of these two majors are not the same. Khanh [16] proves that ESP teaching quality can be enhanced by multiple analysis and synergistic combination of different factors, in which the collaboration between ESP teachers and teachers of Major is considered as a good solution for improving effectiveness and quality of teaching ESP. It can make use of each group of teacher's 
advantages, enable teachers to learn from each other and share their own experiences, through which teachers not just widen their major knowledge, but also meet learners' various demands.

*Learners' ESP ability assessment methods

It can be denied that quality of a curriculum is shown by outcome products. And the direct measurement for these products is assessment tools. When being at school, assessment tools include frequent tests, individual assignments, group assignments and exams, which allow to quantify the amount of knowledge learners acquiring. While being at work, employees' workability is a measurement of a curriculum. Thuan [17] states that assessing ESP teaching should be based on the possibility to meet learners' real and practical needs. He also drills that assessment should be divided into stages with different factors which encourages both teachers and students to be more active and responsible. It possibly enables educational managers to consider more closely teachers' and learners' demands, and it facilitates students to communicate more thoroughly in their ESP using environment. Hong [18] proposes establishing a set of questions for ESP exam based on the format of TOEFL exam, which seems to be a solution to form a standard measure in ESP teaching and learning quality assessment. It also requires reasonable solutions for each training stages. An effective measurement needs to meet some core criteria to test students' knowledge the most exactly. She formulates a set of 250 questions subdivided into 6 types adapted TOEFL test format, under ESP topics and content taught and extended to make suitable and flexible to ESP testing and examining activities.

\subsection{Research situation on ESP teaching and}

\section{learning outside Vietnam}

There have been a number of outstanding studies on many different aspects of ESP teaching and learning outside Vietnam as follows:

In Nijolè [19], he reaches a conclusion that although learners' learning motivation and goals for ESP and GE are slightly different, various ideas and teaching methods can be transferred to the classes of ESP from the classes of GE and vice versa, giving students the opportunity to acquire better skills in a foreign language. Pleșca [20] proves that ESP is a branch of ELT, narrower than EGP basing on ESP characteristics and development. ESP is determined by learners' specific needs. ESP mentions teaching and learning English for a particular academic area, profession, or focus on learners' certain requirements. Fitria [21] believes that learning ESP is to gain a certain goal. Valuating and analyzing ESP should be considered as a part of teaching and learning ESP, or an approaching method, because it relies on a general belief which is ELT. ESP focuses more on students' certain demands and contextual language. In ELT field, ESP pays more attention to students' need. It mentions to a kind of English for learners with a specific purpose. The aim of ESP is to orient and focus on English designed for certain learners basing on their needs and profession. ESP is developed on figuring out purpose, needs and activities requiring English.

Besides, some researches on teaching and learning English for legal purposes. One of these researchers is conducted by Northcott [22], a lecturer and head of English for Business and Law at Edinburgh University's Institute for Applied Language Studies. She designs and teaches English courses for undergraduate law students, LL.M students and lawyers. In her research, she provides an overview of Legal English teaching for second language English speakers adopting a primarily pedagogical perspective. As specificity of context is as crucial as specificity of content the chapter considers different categories of learners grouped according to their professional or academic purposes and contexts of learning and legal language use. Consideration is also given to the different teaching backgrounds of ESP practitioners involved in teaching English for law. The major contribution made by genre analysis to pedagogical practice especially in the teaching of legal reading and writing skills is acknowledged. Ethnographically oriented research can illuminate specific learning contexts as well as target situations and provide useful information for language educators in designing and implementing courses. Highly specialized legal English teaching 
contexts require equal partnership between ESP practitioners and legal specialists.

In addition, Luczak [23] reveals that most university teachers were not only laymen and had (and still have) no diplomas at law, but also they had no experience in designing ELP courses. Even if they had run ESP courses before, they did not necessarily know how to design an ESP course, because most often they followed the syllabus/content of a chosen course book and did not have to bother about the procedures of the course design process which include: needs analysis, target and present situation analysis, researching learning situation, writing syllabus and materials and finally teaching and evaluating the course. He drills that the teachers must be prepared to be open to change and new challenges. They can be trained in special/occupational purposes course design procedures and prepared how to approach changing conditions during their teaching career. It is vital that the teachers stay willing to confront the changing needs of the market and language learners. In the new situation, the language teachers should be ready to gain new content knowledge, master new techniques and test new methods which will lead them towards working out their own teaching "know-how" and best practice. This can help the teachers enhance their position on the teaching market and help them stand out from the still growing group of ESP/ELP teachers. Waiting for the help from the teaching institution will probably not be the best strategy and a vain hope. It is the teachers' job to show their initiative to develop and to gain new skills. Those teachers who are not afraid of challenges and changes will get a chance to specialize and to build their position on the market. It can be argued that the teaching establishments should support their teaching staff and invest in their training, as it will increase the competitiveness of the institutions. Unfortunately, there is also a very strong competition among the teachers. Therefore, the teachers should show their initiative and resourcefulness and look for the new opportunities of self-education in order to strengthen their skills and convince the teaching establishment's authorities to participate in the process.

\section{Conclusion}

The increasingly significant role of ESP in foreign language teaching field has been proved, therefore researching ESP is necessary and gets lots of scholars' concerns. That is because the paramount goal is to figure out the most facilitated and practical approach that enables educators, teachers and students to maximize their competence in mastering ESP to flourish their future careers in this highly demanded global world of work. This paper is, to some extent, hoped to unveil a part of the panoramic research picture on ESP teaching and learning, and makes a suggestion for further studies.

\section{REFERENCES}

[1] Hyland, K. (2006). English for Academic Purposes: An Advanced Resource Book. London, UK: Routledge.

[2] Strevens, P. (1988). ESP after twenty years: A re-appraisal. In M. Tickoo (Ed.): State of the art (p. 1-13). Singapore, SG: SEAMEO Regional Centre.

[3] Robinson, P. (1991). ESP today: A practitioner's guide. New York, US: Prentice Hall International.

[4] Hutchinson, T., Waters, A. (1987). English for Specific Purposes: A Learning-centred Approach. Cambridge University Press. https://doi.org/10.1017/ CBO9780511733031.

[5] Dudley-Evans, T., \& John, M. J. (1998). Developments in English for Specific Purposes: A multi-disciplinary Approach. Cambridge, UK: Cambridge University Press.

[6] Jordan, R. R. (1997) English for Academic Purposes: A Guide and Resource Book for Teachers. Cambridge: Cambridge University Press.

[7] Harmer, J. (1991). The practice of English language Teaching. London Longman.

[8] Widdowson, H. G. (1990). English for Specific Purposes: Criteria for course design. In Selinker et al. (eds). English for Academic and Technical Purposes: Studies in Honour of Louis Trimble. Rowley. Mass: Newbury House.

[9] Basturkmen, H. (2010). Developing Courses for Professional Purposes. New York: Pelgrave Macmillan 
N.T.H.Lan/No.23_Oct 2021|p.94-102

[10] Dong, Q. L. (2010). English Language for Specific Purpose Teaching - Some Problems on Teaching Syllabus. Language \& Life magazine, 11(193), 27-32. https://vjol.info.vn/index.php/NNDS/article/view/1 5840/14239

[11] Ha, T. T. (2019). Theoretical Framework for English Language for Specific Purpose Syllabus Building for Students Majoring in Graphic Design at National University of Arts Education. Journal of education, 2(446): 53-58.

https://tapchigiaoduc.moet.gov.vn/vi/magazine/ download/ ?download=1\&catid=399\&id=7056

[12] Phuong, L. D. (2017). Theoretical Models for Syllabus Assessment at Language Institution at Hanoi University of Science and Technology. Journal of Education. Special Vol. 4: 102-105. https://tapchigiaoduc.moet.gov.vn/vi/magazine/dow nload/?download=1\&catid=268\&id=4066

[13]. Tsou, W., Chen, F. (2014). ESP program evaluation framework: Description and application to a Taiwanese university ESP program. English for Specific Purposes, 33: 39-53.

https://doi.org/10.1016/j.esp.2013.07.008

[14] Dung, T. X. D., Anh, N. D. C. (2010). Teaching and Learning English Language for Specific Purposes in Current Circumstances: Challenges and Solutions. Hue University Journal of Science, 60: 31-41.

https://hueuni.edu.vn/portal/data/doc/tapchi/60_ 4.pdf

[15] Binh, C. H. (2016). Teaching and Learning English Language for Specific Purposes in Setting of Intergration and Globalization. Nha Trang University Conference Proceedings. Nov.2016.

[16] Khanh, T. M. T. (2016). Collaboration between Teachers of English Language for Specific Purposes and Teachers of Specialization - A Soluton to enhance English Language for Specific
Purpose Teaching. Nha Trang University Conference Proceedings. 32-38.

[17] Thuan, D. N., Long, T. V. (2016). A Solution to Enhance English Language for Specific Purpose Ability for Students at Nha Trang University. Nha Trang University Conference Proceedings.

[18] Hong, T. L. (2016). Employing Tasks in TOEFL in Building a System of Multiple Choice Questions in English for Information and Technology. Journal of Education. Special Vol. 4/2016, 132-135.

https://tapchigiaoduc.moet.gov.vn/vi/magazine/ download/?download=1\&catid=252\&id=3376

[19] Nijole, N. (2006). Teaching English for Specific Purposes. Journal Coactivity: Philology, Educology, 14(4): 80-82.

https://doi.org/10.3846/coactivity.2006.47

[20] Pleșca. G. (2016). The Essence of English for Specific Purposes.

https://www.researchgate.net/publication/32325 4539_The_Essence_of_English_for_Specific_Purp oses.

[21] Fitria, T. N. (2020). Teaching English for Specific Purposes (ESP) to the Students in English Language Teaching (ELT). Journal of English Teaching, 5(1): 55-66.

https://doi.org/10.36456/jet.v5.n01.2020.2276

[22] Northcott, J. (2009). Teaching legal English: Context and cases. In D. Belcher (Ed.), English for specific purposes: Theory and practice (165-185). Ann Arbor, MI: University of Michigan Press.

[23] Luczak. A. (2009). Legal English Courses at Universities by Non-Lawyer Teachers: Towards the Model of Educating Legal English Teachers in Poland. International Journal of Arts and Science. 5(18), 186-197. CD-ROM.ISSN:1944-6934. 